\title{
Emotional Phenomenology and Relationality: Forever the Twain Shall Meet
}

\section{Robert D. Stolorow}

To cite this article: Robert D. Stolorow (2019) Emotional Phenomenology and Relationality: Forever the Twain Shall Meet, Psychoanalytic Inquiry, 39:2, 123-126, DOI: 10.1080/07351690.2019.1561126

To link to this article: https://doi.org/10.1080/07351690.2019.1561126

\section{曲 Published online: 18 Mar 2019.}

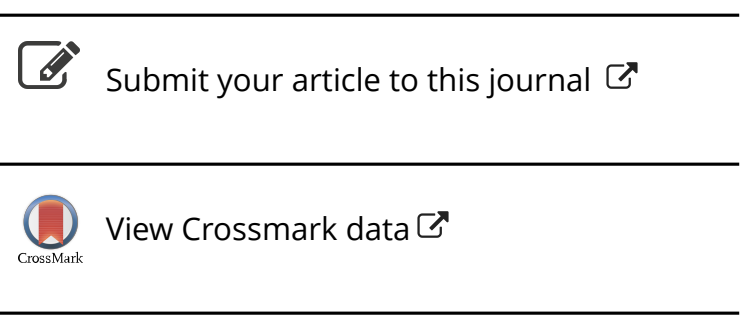




\title{
Emotional Phenomenology and Relationality: Forever the Twain Shall Meet
}

\author{
Robert D. Stolorow, Ph.D.
}

\begin{abstract}
For more than four decades, George Atwood and I have been absorbed in rethinking psychoanalysis as a form of phenomenological inquiry. In the course of this work, I repeatedly made the claim that phenomenology led us inexorably to relationality, but until now I did not offer an explanation of this inexorability. In this article, I show that emotional phenomenology and relationality always already form an indissoluble unity, because relationality is constitutive of emotional experience.
\end{abstract}

\begin{abstract}
A science is defined by its domain of inquiry. In its most general form, our thesis ... is that psychoanalysis seeks to illuminate phenomena that emerge within a specific psychological field constituted by the intersection of two subjectivities - that of the patient and that of the analyst. In this conceptualization, psychoanalysis is not seen as a science of the intrapsychic, focused on events presumed to occur within one isolated "mental apparatus." Nor is it conceived as a social science, investigating the "behavioral facts" of the therapeutic interaction as seen from a point of observation outside the field under study. Rather, psychoanalysis is pictured here as a science of the intersubjective, focused on the interplay between the differently organized subjective worlds of the observer and the observed. The observational stance is always one within, rather than outside, the intersubjective field ... being observed. ... Psychoanalysis is unique among the sciences in that the observer is also the observed. [Atwood and Stolorow, 1984, pp. 41-42]
\end{abstract}

We contend that both psychological development and pathogenesis are best conceptualized in terms of the specific intersubjective contexts that shape the developmental process and that facilitate or obstruct the child's negotiation of critical developmental tasks and successful passage through developmental phases. The observational focus is the evolving psychological field constituted by the interplay between the differently organized subjectivities of child and caretakers. [Atwood and Stolorow, 1984, p. 65]

Although certain authors have, for political reasons, sought to marginalize and isolate Atwood's and my intersubjective-systems perspective, Mitchell and Aron (1999), in their introduction to our chapter in their anthology, characterized us as "pioneers" of the relational turn:

Robert Stolorow and George Atwood are among the leading pioneers of the intersubjective approach. It was they and their collaborators in the 1970s who introduced the term intersubjectivity into the vocabulary of the psychoanalytic community in this country. ${ }^{1}$ These authors have long argued for a paradigm shift in the field toward a dynamic systems perspective and have been most articulate and persuasive in their radical critique of "the myth of the isolated mind" ... and so influential for the emerging relational tradition. [pp. 365-366]

The two passages quoted at the beginning of this article show unambiguously that our perspective has been a relational one since its early beginnings. Upon further reflection, however, I have realized that there is something about the development of our relational perspective that distinguishes it from most others. Typically, contemporary relational viewpoints have their origins in prior psychoanalytic theoriesSullivan's, Klein's, Fairbairn's, etc. ${ }^{2}$ In contrast, our perspective evolved from considerations of methodnamely, our commitment to rethinking psychoanalysis as a form of phenomenological inquiry. Indeed, the

CONTACT Robert D. Stolorow, Ph.D. robertdstolorow@gmail.com E 744 21st Place, Santa Monica, CA 90402.

${ }^{1}$ In Stolorow, Atwood, and Ross (1978).

${ }^{2}$ These prior psychoanalytic theories often contain concepts that are instantiations of Cartesian isolated-mind thinking-such as parataxic distortion, projective identification, and endopsychic structures-that are carried over more or less uncritically into the corresponding contemporary relational viewpoints (see Stolorow, Atwood, and Orange, 2002, Chapter 5).

Copyright $\odot$ Melvin Bornstein, Joseph Lichtenberg, Donald Silver 
subtitle of the book (Atwood and Stolorow, 1984) from which my opening quotations are drawn is Explorations in Psychoanalytic Phenomenology. Let me explain further.

The historical origins of our phenomenological perspective harken back to a series of psychobiographical studies that we conducted in the early and mid-1970s, of the personal, subjective origins of the theoretical systems of Freud, Jung, Reich, and Rank, studies that formed the basis of our first book, Faces in a Cloud: Subjectivity in Personality Theory (Stolorow and Atwood, 1979), which was completed in 1976. From these studies we concluded that because psychoanalytic theories derive to a significant degree from the subjective concerns of their creators, what psychoanalysis needed was a theory of subjectivity itself-a unifying framework capable of accounting not only for the psychological phenomena that other theories address, but also for the theories themselves.

In the last chapter of Faces (Stolorow and Atwood, 1979) we outlined a set of proposals for the creation of such a framework, which, as I alluded to, we called psychoanalytic phenomenology. Influenced by the work of George S. Klein (1976), we envisioned this framework as a depth psychology of personal experience, purified of the mechanistic reifications of Freudian metapsychology. Our framework took the experiential world of the individual as its central theoretical construct. We assumed no impersonal psychical agencies or motivational prime movers to explain the experiential world. Instead, we assumed that this world evolves organically from the person's encounter with the critical formative experiences that constitute his or her unique life history. Once established, it becomes discernible in the distinctive, recurrent patterns, themes, and invariant meanings that prereflectively organize the person's experiences. Psychoanalytic phenomenology entailed a set of interpretive principles for investigating the nature, origins, purposes, and transformations of the configurations of self and other pervading a person's experiential world. Importantly, our dedication to illuminating personal phenomenology had led us from mind to world and thus from mental contents to relational contexts, from the intrapsychic to the intersubjective. From our phenomenological perspective, all of the clinical phenomena with which psychoanalysis has been traditionally concerned were seen as taking form within systems of interacting, differently organized, mutually influencing subjective worlds. Phenomenology had led us inexorably to contextualism. ${ }^{3}$

How and why did this inexorable movement from phenomenology to contextualism occur? ${ }^{4}$ The central reason, I have come to realize, is that a psychoanalytic phenomenology, as opposed to other forms of phenomenological inquiry, is always devoted to investigating affectivity-that is, worlds of emotional experience. During the period when George Atwood and I were fleshing out our psychoanalytic phenomenology, I was working on an article with Daphne Socarides Stolorow (Socarides and Stolorow, 1984/85) in which we were suggesting that Kohut's central clinical contributions pertained essentially to affective experience. Furthermore, the experience of affect was grasped in this article as being inseparable from the contexts of attunement and malattunement in which it is felt. This understanding became seamlessly woven into the fabric of psychoanalytic phenomenology.

The shift in focus from the primacy of drive to the primacy of affectivity moves psychoanalysis toward a phenomenological contextualism and a central focus on dynamic intersubjective systems. Unlike drives, which are claimed to originate deep within the interior of a Cartesian isolated mind, affect-subjective emotional experience-is something that from birth onward is coconstituted within ongoing relational systems. Therefore, locating affect at its center automatically entails a radical contextualization of virtually all aspects of human psychological life.

\footnotetext{
${ }^{3}$ Later (Stolorow, 2011), I found in Heidegger's (1927) ontological contextualism (In-der-Welt-sein) a philosophical foundation for our psychoanalytic phenomenological contextualism, replacing the Cartesian isolated mind that undergirds Freudian theory.

${ }^{4} \mathrm{~A}$ similar progression can be discerned in the evolution of Kohut's ideas. In his early article (Kohut, 1959) on the relationship between mode of observation and theory in psychoanalysis, he conceived of psychoanalysis as a form of phenomenological inquiry, without naming it as such, by arguing that only what is accessible to empathy and introspection belongs within the domain of psychoanalytic theory. In his subsequent important contributions to psychoanalytic clinical theory (e.g., Kohut, 1971), he claimed famously that the experiencing of selfhood, or of its collapse, is always embedded in a relational context. Still later (Kohut, 1977), he unfortunately moved away from both phenomenology and contextualism by positing "the self" as a metaphysical entity with thing-like properties ( $p . x v)$.
} 
For example, the focus on affect contextualizes the very boundary between conscious and unconscious. Unlike the Freudian repression barrier, viewed as a fixed intrapsychic structure within an isolated Cartesian container, the limiting horizons of emotional experiencing are conceptualized as emergent properties of ongoing dynamic intersubjective systems. Forming and evolving within a nexus of living systems, the horizons of experiencing are grasped as fluid and ever-shifting, products both of the person's unique intersubjective history and of what is or is not allowed to be felt within the intersubjective fields that constitute his or her current living.

In my experience, a consistently phenomenological approach has also been especially fruitful in the effort to grasp the context-embeddedness of emotional trauma (Stolorow, 2007). ${ }^{5}$ From a phenomenological perspective, developmental trauma is viewed, not as an instinctual flooding of an ill-equipped Cartesian container, as Freud (1926) would have it, but as an experience of unbearable affect. Furthermore, the intolerability of an affect state cannot be explained solely, or even primarily, on the basis of the quantity or intensity of the painful feelings evoked by an injurious event. Traumatic affect states can be grasped only in terms of the relational systems in which they are felt. Developmental trauma originates within a formative intersubjective context whose central feature is malattunement to painful affect-a breakdown of the child-caregiver interaffective system, leading to the child's loss of affect-integrating capacity and thereby to an unbearable, overwhelmed, disorganized state. Painful or frightening affect becomes traumatic when the context of emotional understanding-the relational home-that the child needs to assist in its tolerance and integration is profoundly absent. Such contexts of developmental trauma are where pathogenesis takes form.

Corresponding to the relational constitution of emotional trauma, I have recommended an active, relationally engaged form of therapeutic comportment that I call emotional dwelling (Stolorow, 2014). In dwelling, one does not merely seek empathically to understand the other's emotional pain from the other's perspective. One does that, but much more. In dwelling, one leans into the other's emotional pain and participates in it, perhaps with aid of one's own analogous experiences of pain. The language that one uses to address another's experience of emotional trauma meets the trauma head-on, articulating the unbearable and the unendurable, saying the unsayable, unmitigated by any efforts to soothe, comfort, encourage, or reassure-such efforts invariably being experienced by the other as a shunning or turning away from his or her traumatized state. In dwelling, by contrast, the therapist can become established as a relational home for the unbearable emotional pain.

In work too voluminous to review here, my collaborators and I, in an abundance of articles and books written over a period of nearly four decades, have shown that the intersubjective context plays a constitutive role in all forms of pathogenesis and in all aspects of the psychoanalytic process. ${ }^{6}$ What I am emphasizing now is that emotional phenomenology and relationality always already form an indissoluble unity, because relationality is constitutive of emotional experience.

\section{Notes on contributor}

Robert D. Stolorow, Ph.D., is a Founding Faculty Member at the Institute of Contemporary Psychoanalysis, Los Angeles, and at the Institute for the Psychoanalytic Study of Subjectivity, New York. Absorbed for more than four decades in the project of rethinking psychoanalysis as a form of phenomenological inquiry, he is the author of World, Affectivity, Trauma: Heidegger and Post-Cartesian Psychoanalysis (Routledge, 2011) and Trauma and Human Existence: Autobiographical, Psychoanalytic, and Philosophical Reflections (Routledge, 2007) and coauthor of eight other books. He received his Ph.D. in Clinical Psychology from Harvard in 1970 and his Ph.D. in Philosophy from the University of California at Riverside in 2007.

\footnotetext{
${ }^{5}$ Additionally, Heidegger's (1927) analysis of Angst, world-collapse, uncanniness, and thrownness into Being-toward-death provided me with extraordinary philosophical tools for grasping the existential meanings of emotional trauma (Stolorow, 2011). ${ }^{6}$ Such context-sensitivity is seen with particular vividness when working with the phenomenology of psychotic states (Atwood, 2011).
} 


\section{References}

Atwood, G. E. (2011), The Abyss of Madness. New York: Routledge.

, \& R. D. Stolorow. (1984), Structures of Subjectivity: Explorations in Psychoanalytic Phenomenology. Hillsdale, NJ: The Analytic Press.

Freud, S. (1926), Inhibitions, symptoms and anxiety. Standard Edition, 20: 77-175. London: Hogarth Press, 1959. Heidegger, M. (1927), Being and Time, trans. J. Macquarrie and E. Robinson. New York: Harper and Row, 1962.

Klein, G. S. (1976), Psychoanalytic Theory: An Exploration of Essentials. New York: International Universities Press.

Kohut, H. (1959), Introspection, empathy, and psychoanalysis. J. Amer. Psychoanal. Assn., 7: 459-483. (1971), The Analysis of the Self. New York: International Universities Press. (1977), The Restoration of the Self. New York: International Universities Press.

Mitchell, S. A., \& L. Aron, eds. (1999), Relational Psychoanalysis: The Emergence of a Tradition. Hillsdale, NJ: The Analytic Press.

Socarides, D. D., \& R. D. Stolorow. (1984/85), Affects and selfobjects. Ann. Psychoanal., 12/13: 105-119. Madison, CT: International Universities Press.

Stolorow, R. D. (2007), Trauma and Human Existence: Autobiographical, Psychoanalytic, and Philosophical Reflections. New York: Routledge. . (2011), World, Affectivity, Trauma: Heidegger and Post-Cartesian Psychoanalysis. New York: Routledge. - (2014), Undergoing the situation: Emotional dwelling is more than empathic understanding. Internat. J. Psychoanal. Self Psych., 9: 80-83. , \& G. E. Atwood. (1979), Faces in a Cloud: Subjectivity in Personality Theory. Northvale, NJ: Jason Aronson. , G. E. Atwood, \& D. M. Orange. (2002), Worlds of Experience: Interweaving Philosophical and Clinical Dimensions in Psychoanalysis. New York: Basic Books.

, G. E. Atwood, \& J. M. Ross. (1978), The representational world in psychoanalytic therapy. Internat. Rev. Psycho-Anal., 5: 247-256. 